D'Entremont, K. J. N., L. Minich Zitske, A. J. Gladwell, N. K. Elliott, R. A. Mauck, and R. A. Ronconi. 2020. Breeding population decline and associations with nest site use of Leach's Storm-Petrels on Kent Island, New Brunswick from 2001 to 2018 . Avian Conservation and Ecology 15(1):11. https://doi.org/10.5751/ACE-01526-150111

Copyright (C) 2020 by the author(s). Published here under license by the Resilience Alliance.

Research Paper

\title{
Breeding population decline and associations with nest site use of Leach's Storm-Petrels on Kent Island, New Brunswick from 2001 to 2018
}

\author{
Kyle J. N. d'Entremont ${ }^{1,2}$, Laura Minich Zitske ${ }^{3,4}$, Alison J. Gladwell ${ }^{1}$, Nathan K. Elliott ${ }^{3,5}$, Robert A. Mauck ${ }^{6}$ and Robert A. Ronconi \\ ${ }^{1}$ Dalhousie University, Canada, ${ }^{2}$ Memorial University of Newfoundland, Canada, ${ }^{3}$ Bowdoin College, USA, ${ }^{4}$ Maine Audubon, \\ USA, ${ }^{5}$ Point Blue Conservation Science, USA, ${ }^{6}$ Kenyon College, USA, ${ }^{7}$ Canadian Wildlife Service, Environment and Climate \\ Change Canada, Dartmouth, NS, Canada, ${ }^{8}$ Department of Biology, Dalhousie University, Halifax, NS, Canada
}

\begin{abstract}
Leach's Storm-Petrels (Hydrobates leucorhous) are burrow-nesting seabirds that breed on coastal islands throughout much of the North Atlantic, with most of the world's population breeding in Atlantic Canada. Population declines in the past 20-30 years have resulted in the species being uplisted to "Vulnerable" on the International Union for the Conservation of Nature Red List of Threatened Species. One of the species' most well-studied colonies is on Kent Island, New Brunswick in the Bay of Fundy. To determine if this colony has faced declines over a similar timescale, census work was conducted in June and July of 2000/2001 and 2018. Forty-one east-west transects in 2000/2001 (516 plots) and 56 east to west transects in 2018 (678 plots) were established every 50 $\mathrm{m}$ along the length of the island, which were censused with $10 \mathrm{~m}^{2}$ plots. Population estimates were calculated by extrapolating mean occupied burrow density over the area of suitable nesting habitat on the island. Additionally, habitat characteristics and predator presence were recorded within each plot, and classification and regression tree (CART) analysis was used to determine which environmental factors affected burrow densities and occupancy rate. The estimated number of breeding pairs for the entire island in 2018 was 21,643 (CI 16,942-26,343) and has declined at an annual rate of $-1.79 \%$ (CI $-3.28 \%$ to $-0.25 \%$ ) since $2000 / 2001$ (29,416 CI 23,015-35,817 pairs), though population trends varied across the island with forested habitat experiencing a large decline and the open habitat experiencing a marginal increase. CART models revealed that occupied burrow densities were highest in areas dominated by ferns or shrub/bramble that had no signs of forest regrowth, and had low gull nesting densities. Our results suggest that Leach's StormPetrels are declining at the southern extent of their range at similar rates exhibited at northern colonies, especially in forested habitat where habitat change may be influencing nest-site use.
\end{abstract}

\section{Déclin de la reproduction de la population et associations avec l'utilisation des sites de nidification des pétrels cul-blanc sur Kent Island, dans le Nouveau-Brunswick, de 2001 à 2018}

RÉSUMÉ. Les pétrels cul-blanc (Hydrobates leucorhous) sont des oiseaux marins nichant dans des terriers, qui se reproduisent sur les îles côtières le long d'une grande partie de la côte nord-Atlantique, principalement le long de la côte Atlantique du Canada. Leur population a décliné au cours de 20 à 30 dernières années, de sorte que cette espèce est désormais classée comme « vulnérable » sur la Liste rouge des espèces menacées de Union Internationale pour la Conservation de la Nature. L'une des colonies les plus étudiées de cette espèce habite Kent Island, dans le Nouveau-Brunswick, dans la baie de Fundy. Pour déterminer si cette colonie a décliné au cours de la même période, un recensement a été effectué en juin et juillet 2000/2001 et 2018. Quarante-et-un transects est-ouest en 2000/2001 (516 parcelles) et 56 transects est-ouest en 2018 (678 parcelles) étaient établis tous les $50 \mathrm{~m}$ tout le long de l'île, leur superficie individuelle ayant été recensée à $10 \mathrm{~m}^{2}$. Les estimations de population ont été effectuées par extrapolation de la densité moyenne d'occupation des terriers sur la zone de l'habitat de nidification appropriée sur l'île. En outre, les caractéristiques de l'habitat et la présence de prédateurs ont été enregistrées sur chaque parcelle et une analyse par arbres de régression et de classification (CART) a été utilisée pour déterminer les facteurs environnementaux qui affectaient la densité des terriers et leur taux d'occupation. Le nombre estimé de couples reproducteurs sur l'ensemble de l'île s'établissait à 21643 en 2018 (IC 16 942-26 343) et a décliné selon un taux annuel de -1,79\% (IC -3,78 \% à -0,25\%) depuis 2000/2001 (29 416 IC 23 015-35 817 couples), bien que les tendances de la population aient varié dans l'île : on a en effet constaté un important déclin dans l'habitat forestier et une légère augmentation dans l'habitat ouvert. Les modèles CART ont révélé que la densité d'occupation des terriers était plus élevée dans les zones de fougères ou de buissons/ronciers qui ne présentaient pas de signes de reforestation et où la densité de nidification de goélands était faible. Nos résultats suggèrent que les pétrels cul-blanc sont en déclin à la pointe sud de leur territoire selon un taux similaire à celui que l'on constate pour les colonies du nord, en particulier dans les habitats forestiers, dont les transformations peuvent influencer l'utilisation des sites de nidification.

Key Words: census; habitat; Kent Island; Leach's Storm-Petrel; nest site use; population change; predation 


\section{INTRODUCTION}

Marine birds serve as valuable indicators for the status of marine ecosystems owing to their vulnerability to anthropogenic impacts including oil pollution (Wiese and Robertson 2004), plastic ingestion (Provencher et al. 2014, Wilcox et al. 2015), fisheries bycatch (Anderson et al. 2011), and shifts in prey distribution and availability associated with oceanic climate change (Davoren and Montevecchi 2003, Buren et al. 2012) as well as commercial fisheries (Cury et al. 2011). Population trends of seabird species yield inference to how marine ecosystems are responding to these anthropogenic stressors and environmental changes (Croxall et al. 2002, Piatt et al. 2007, Goyert et al. 2018). Seabirds in the Procellariform order are particularly vulnerable to these stressors and environmental changes because of their prolonged chick rearing periods, low fecundity, and long-term mate and nest site fidelity (Rodríguez et al. 2019).

The Leach's Storm-Petrel (Hydrobates leucorhous; hereafter storm-petrel) is an abundant pelagic seabird belonging to the Procellariform order that nests in burrows on islands throughout the North Pacific and North Atlantic oceans, with the majority breeding in Atlantic Canada (Pollet et al. 2019). Population declines have been observed at many major colonies throughout this region in the past 20-30 years (Robertson et al. 2006, Wilhelm et al. 2015, Pollet and Shutler 2018), including the largest colony in the world on Baccalieu Island, Newfoundland and Labrador (Wilhelm et al. 2019). These declines have resulted in storm-petrels being uplisted globally from "Least Concern" to "Vulnerable" status (BirdLife International 2018), and because the reasons for these declines are largely unknown, monitoring population trends at colonies provides vital information for the management and conservation of this species.

Although it is crucial to conduct surveys to understand population change, it is also important to assess drivers that might be influencing these trends. Though marine birds are exposed to many stressors at sea (Davoren and Montevecchi 2003, Wiese and Robertson 2004, Anderson et al. 2011, Cury et al. 2011, Buren et al. 2012, Provencher et al. 2014), population trends may also be impacted by stressors occurring at the breeding colony, such as changes in the availability of suitable habitat (Stenhouse and Montevecchi 1999, Hipfner et al. 2010, Brodier et al. 2011, Shaw et al. 2011). Habitat selection theory suggests that individuals nesting in higher quality habitats will achieve greater fitness than individuals nesting in lower quality habitat (Fretwell and Lucas 1969). Colonially nesting seabirds have been shown to emigrate from their less successful breeding grounds to more suitable habitat (Danchin et al. 1998, Schjørring et al. 2000, Stenhouse et al. 2000). Therefore, changes in nesting densities, occupancy rates, and overall population sizes within seabird colonies may be indicative of shifts in habitat quality or suitability within the colony.

Kent Island, New Brunswick is home to a substantial and wellstudied colony of storm-petrels that has been monitored since the late 1930 s, though population estimates have been infrequent, assessed from limited sampling, and/or lacked extensive spatial coverage of the island (Gross 1935, Wilbur 1969, Cannell and Maddox 1983). Previous estimates placed the population of Kent Island from $\sim 2000$ to $\sim 15,000$ pairs (Gross 1935, Wilbur 1969, Cannell and Maddox 1983) and though this represents $<1 \%$ of the global population, this colony is among the 10 largest colonies in Atlantic Canada. In recent years, there has been a dramatic change in habitat types on Kent Island. A long-standing introduced population of invasive snowshoe hares (Lepus americanus) was eradicated in 2007, allowing young forest to replace areas previously dominated by ferns and raspberry brambles. In 2008, an outbreak of bark beetles destroyed a large portion of the island's mature white spruce (Picea glauca; Wheelwright 2016). These factors may have impacted habitat suitability for storm-petrels nesting on the island.

Kent Island and its neighboring islands also support a large population of Herring Gulls (Larus argentatus) and a couple dozen Great Black-backed Gulls (Larus marinus; Ronconi and Wong 2003, Bennett et al. 2017) and storm-petrels are known to form a small, but consistent portion of their diets (Steenweg et al. 2011). Predation by gulls has greatly impacted populations of several storm-petrel species worldwide (Oliveira 2016, Ainley et al. 2019) and small storm-petrel colonies in Atlantic Canada have suffered steep declines in the face of predation by Herring Gulls and Great Black-backed Gulls nesting nearby (Robertson et al. 2006). Thus, quantifying relationships between habitat characteristics, gull nesting densities, burrow densities, and occupancy rates on Kent Island could provide insight into nesting habitat suitability that may have an influence on population changes for this species.

This study estimates the population size of Leach's Storm-Petrels nesting on Kent Island, New Brunswick across a 17-year time span (2000/2001 and 2018) during which population declines have been observed elsewhere in their range. Additionally, we aimed to determine what effects, if any, varying habitat characteristics and predator presence has on nest site use by storm-petrels on Kent Island by using occupied burrow density, occupied burrow presence and occupancy rate as a proxy for habitat suitability.

\section{METHODS}

\section{Study area}

Kent Island $\left(44.5819^{\circ} \mathrm{N}, 66.7559^{\circ} \mathrm{W}\right)$, New Brunswick is $2.8 \mathrm{~km}$ long and about $0.7 \mathrm{~km}$ at its widest. With a total area of approximately 80 ha, it is the largest of the Three Islands group within the Grand Manan Archipelago in the Bay of Fundy. The island is home to New Brunswick's largest Leach's Storm-Petrel colony and is located near the southern extent of the species' breeding range in the North Atlantic. The northern half of the island is predominantly dense forest composed of primarily yellow birch (Betula alleghaniensis), white spruce, balsam fir (Abies balsamea) and mountain ash (Sorbus americana), except for the northernmost $200 \mathrm{~m}$, which is dominated by fern, grasses, and thicket. The southern region of the island is predominantly fern, grass, and raspberry thicket and is the site of most of the island's Herring Gull and Great Black-backed Gull populations, though some nest around the forest perimeter in the north. Though habitat types vary greatly across the island, storm-petrels nest in varying degrees throughout, with the exception of the dry, compacted soils of an elevated field in the central region of the island (Fig. 1).

\section{Breeding pair population census}

A complete census of the storm-petrel breeding population on Kent Island was conducted by one observer from 1 June until 28 July in 2000 and from 10 June until 27 July in 2001 and by two 
observers from 11 June until 24 July in 2018. Mean lay date on Kent Island from 2006 to 2018 in burrows monitored throughout the breeding season was 19 June $\pm 12.63 \mathrm{SD}$ days $(\mathrm{N}=1916)$. Chicks begin to fledge in late August and September (Pollet et al. 2019).

Fig. 1. Kent Island divided into a predominantly forested north section (blue; 411,260 $\mathrm{m}^{2}$ ) and predominantly open south section (white; 447,098 $\mathrm{m}^{2}$; panel a). Points indicate distribution of $1 \times 10 \mathrm{~m}$ survey plots with red symbols indicating plots that contained occupied Leach's Storm-Petrels (Hydrobates leucorhous) burrows in 2000/2001 (b) and 2018 (c), and plots with gull nests in 2018 (d).

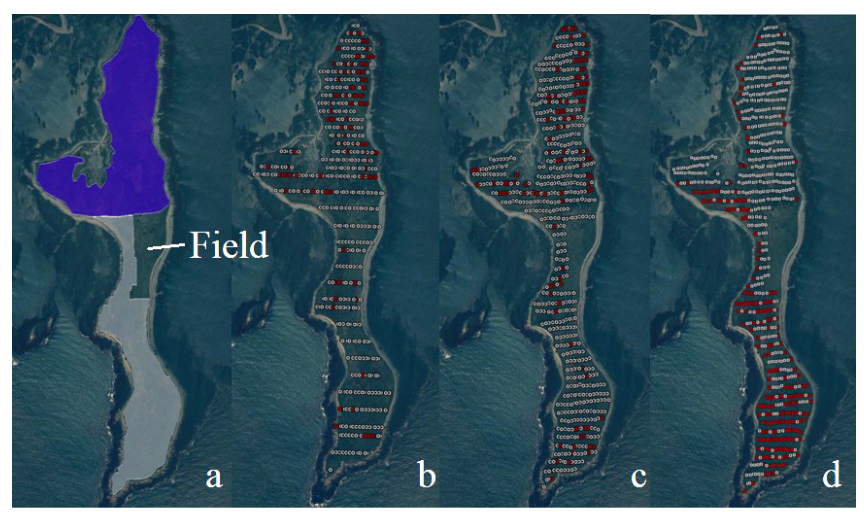

Transects were sampled across the width of the island, except within a field ( $\sim 7 \mathrm{ha})$ in the central portion of the island, which is an area not known to support breeding storm-petrels because of compacted soils and managed (mowed) vegetation (see Fig. 1). In 2000/2001, 41 east-to-west transects were established across the north-south axis of the island. In 2018, 56 east to west transects were established every $50 \mathrm{~m}$ throughout the entire length of the island, ordered from north to south. In 2018, even numbered transect lines $(100,200,300 \mathrm{~m}$, etc.) were sampled first (11 June to 1 July), then alternate lines (50, 150, $250 \mathrm{~m}$, etc.) were sampled later (1 July to 24 July), spreading out sampling across both space and time. Additionally, for purposes of population estimates, the island was subdivided into two regions, the northern half of the island, which is predominantly forested and has traditionally been known to support large numbers of stormpetrels (Pollet et al. 2019; R Mauck, unpublished data), and the southern half, which is predominantly open habitat and has been largely ignored by previous censuses (Cannell and Maddox 1983). The north half spans the northernmost $1200 \mathrm{~m}$ of the island, while the southern half spans the remainder. Sampling effort was equal during both surveys in the northern region of the island $(n=20$ transects). The sampling regime was more extensive in the southern half of the island in 2018 ( $n=36$ transects) than the $2000 / 2001$ census ( $n=21$ transects). The total area of potentially suitable habitat on the island is $716,407 \mathrm{~m}^{2}$ as determined by drawing polygons on Google Earth Pro. The areas of potentially suitable habitat for the north and south regions were determined to be $269,309 \mathrm{~m}^{2}$ and $447,098 \mathrm{~m}^{2}$, respectively (Fig. 1a).

Along each transect, $1 \times 10 \mathrm{~m}$ plots were established at every other $10 \mathrm{~m}$ point until the high tide mark was reached at either end, resulting in 516 plots in 2000/2001 and 687 plots in 2018. Each plot was searched thoroughly for storm-petrel burrows and each burrow was examined to determine occupancy. All burrows $>30$ $\mathrm{cm}$ in length found within plots were counted and burrows were deemed to be occupied if there was an egg or chick present (Wilhelm et al. 2015). Secondary entrances were created for burrows that were too long; if the end still could not be reached, these burrows were classified as unoccupied to provide the most conservative estimate because we were unable to verify their contents $(6.25 \%$ of all burrows in $2000 / 2001$ and $3.42 \%$ of all burrows in 2018). Any signs of predation on storm-petrels (wings, feathers, carcasses) seen within $10 \mathrm{~m}$ of each plot were also recorded in 2018.

A handheld Global Positioning System (GPS) device was used to record coordinates for all plots that were surveyed during both study periods (Fig. 1). Thirty-three plots in 2001 and nine plots along the $1200 \mathrm{~m}$ transect in 2018 in the central field confirmed absence of petrel burrows in this habitat and, therefore, were omitted from analysis.

\section{Habitat variables}

Habitat variable data was recorded for each $1 \times 10 \mathrm{~m}$ plot surveyed for storm-petrel burrows and occupancy in 2000/2001 and 2018. These parameters were then included in classification and regression tree (CART) models in order to assess associations between habitat parameters and storm-petrel presence and abundance. Data recorded for habitat type included \% canopy closure, dominant canopy and understory vegetation, and presence of deadfall for both study periods. Canopy closure was estimated and classified into five categories: open habitat, $1-25 \%$, $25-50 \%, 50-75 \%$, and $75-100 \%$ closure. Dominant canopy was classified into six categories: alder, ash, birch, fir, spruce, and open. Dominant understory is the main vegetation type at ground level, and was classified into seven categories: fern, grass, shrub/ bramble (raspberry thicket, gooseberry, blueberry, sheep laurel), moss, aster, goldenrod, and miscellaneous low vegetation.

During the 2018 census, we also recorded signs of forest regrowth, soil moisture, and predator presence. Signs of forest regrowth was simply categorized as presence or absence of young forest $(<2.5$ $\mathrm{m}$ height) and/or saplings. Soil moisture was measured with a Vernier LabQuest2 with a soil moisture sensor probe attachment, which was inserted $\sim 5 \mathrm{~cm}$ below the surface in the center of each plot. Data recorded for presence of predators (gulls) was the number of gull nests within $10 \mathrm{~m}$ of each plot, which was used as a parameter because of the low probability of finding gull nests within plots, therefore we searched for gull nests over a larger area surrounding plots as an index for nearby gull nesting density.

\section{Data analysis}

\section{Breeding pair estimate}

Total burrow density (occupied and unoccupied burrows) and occupied burrow density was calculated for each plot by dividing the number of burrows within the plot by the area sampled (10 $\mathrm{m}^{2}$ ). Occupancy rates for the north and south regions and for the island as a whole were calculated by dividing the number of burrows occupied by the total number of burrows, occupied or otherwise. Independent samples t-tests were conducted in order to test for significant differences in occupancy rates of the north and south regions across study periods (2000/2001 to 2018). 
Table 1. Total area, number of plots surveyed, number of occupied burrows, mean burrow density (per m²), mean occupied burrow density $\left(\right.$ per $\mathrm{m}^{2}$ ), and occupancy rate of Leach's Storm-Petrels (Hydrobates leucorhous) nesting on Kent Island, New Brunswick in 2000/2001 and 2018.

\begin{tabular}{|c|c|c|c|c|c|c|c|}
\hline Year & Location & $\begin{array}{l}\text { Total Area } \\
\left(\mathrm{m}^{2}\right)\end{array}$ & Plots $\left(10 \mathrm{~m}^{2}\right)$ & Active Burrows & $\begin{array}{l}\text { Mean Burrow Density } \\
\text { (SE) }\end{array}$ & $\begin{array}{c}\text { Mean Occupied Burrow } \\
\text { Density (SE) }\end{array}$ & $\begin{array}{c}\text { Occupancy Rate } \\
\text { (SE) }\end{array}$ \\
\hline \multirow[t]{3}{*}{$2000 / 2001$} & North & 411260 & 299 & 181 & $0.1180(0.010)$ & $0.0605(0.007)$ & $0.51(0.03)$ \\
\hline & South & 308472 & 217 & 32 & $0.0263(0.006)$ & $0.0147(0.005)$ & $0.56(0.07)$ \\
\hline & Entire Island & 719732 & 516 & 213 & & & \\
\hline \multirow[t]{3}{*}{2018} & North & 411260 & 387 & 153 & $0.0677(0.007)$ & $0.0395(0.005)$ & $0.58(0.03)$ \\
\hline & South & 308472 & 291 & 51 & $0.0306(0.006)$ & $0.0175(0.004)$ & $0.57(0.05)$ \\
\hline & Entire Island & 719732 & 678 & 204 & & & \\
\hline
\end{tabular}

Breeding pair estimates were calculated by multiplying the mean occupied burrow density of each region of the island by the total area of each region. Though occupied burrow density in plots was heavily skewed to the left, we had a large enough sample size that the estimates of mean occupied burrow density met the assumptions of the central limit theorem (Catry et al. 2003) and therefore population estimates and confidence limits can be calculated using standard procedures. The associated $95 \%$ confidence intervals for breeding pair estimates were calculated by multiplying the standard error (SE) by the returned inverse of the t-distribution ( $\mathrm{df}=$ number of plots; Wilhelm et al. 2015) and either adding or subtracting from the total breeding pair estimate. The breeding pair estimate SE for the north and south regions of the island were calculated by multiplying the total area of each region by the SE of the occupied burrow density for each region. The breeding pair estimate SE for the entire island was calculated by taking the square root of the breeding pair estimate SE from the north squared added to the breeding pair estimate SE from the south squared. Unpaired t-tests were conducted to test significance between breeding pair estimates across study periods.

The annual rate of change for the number of breeding pairs from 2001 to 2018 was determined for the north, south, and entire island by using the following equation for discrete population growth, where $\lambda$ is the annual rate of change, $N(t)$ is population size at time $t, N(0)$ is population size at time 0 , and $t$ is the time between surveys.

$$
\lambda=\exp ((\ln (\mathbf{N}(\mathbf{t}) / \mathbf{N}(0))) / t)
$$

The percent annual change is then calculated by subtracting 1 from $\lambda$ and multiplying by 100 . In order to account for variance in population estimates, vectors consisting of 10,000 random draws of the mean population size and standard error were created following a normal distribution for both 2000/2001 and 2018 . Annual rates of change $(\lambda)$ were then calculated from these vectors and $95 \%$ confidence intervals were extracted.

\section{Nest site use}

To determine which habitat factors were associated with burrow presence, burrow densities, and occupancy rates, CART analysis was used. CART analysis has been used extensively in habitat and nest site use studies (Clark et al. 1999, Maslo et al. 2011, Fricke et al. 2015) owing to their ability to (1) model complex ecological data with nonlinear relationships and missing values (De'ath and
Fabricius 2000), (2) recognize critical threshold values for explanatory variables on a dependent variable, and (3) avoid a priori assumptions of relationships between a response variable and predictor variables (Guisan and Zimmerman 2000). CART analysis resolves relationships between a single response variable and several predictor variables, which may be categorical or numeric (De'ath and Fabricius 2000). Three separate CART models were created for each study period with (1) occupied burrow density, (2) occupied burrow presence, and (3) occupancy rate as the response variable. Predictor variables in analyses included dominant canopy (8 categories), dominant understory vegetation type ( 7 categories), soil moisture, canopy closure (5 categories), presence of forest regrowth (yes or no), presence of deadfall (yes or no), and number of gull nests within $10 \mathrm{~m}$ of plots. CART analysis was completed by using the $\mathrm{R}$ package "party" (Hothorn et al. 2006) in the statistical software R 3.5.1 (R Core Team 2018). Splits in the model were based on hypothesis testing criterion within the R package "party" and the Bonferroni adjusted P-values (0.05) that were associated with these splits (Hothorn et al. 2006).

\section{RESULTS}

Across 41 transects in 2000/2001, 19.6\% of 516 searched plots contained at least one occupied burrow. Along 56 transects surveyed in $2018,15.9 \%$ of 678 searched plots contained at least one occupied burrow. During both the 2000/2001 and 2018 study periods, burrow densities were higher in the mainly forested north end of the island compared to the mainly open south end. Changes between these periods show decreasing burrow densities in the north, and stable or increasing burrow densities in the south (Table 1).

Occupancy rates have not changed significantly in either the north $(\mathrm{t}=-0.473, \mathrm{df}=45, \mathrm{P}=0.639)$ or south region $(\mathrm{t}=-0.738, \mathrm{df}=$ $48, \mathrm{P}=0.464$ ) of the island between 2000/2001 and 2018 (Table 1). Occupancy rates (mean \pm SE) across the six-week study period in 2018 from the first week through to the last week of the study were as follows; $0.51 \pm 0.05,0.49 \pm 0.05,0.66 \pm 0.05,0.68 \pm 0.04$, $0.46 \pm 0.05$, and $0.61 \pm 0.05$. In 2018 , occupancy rates did not vary significantly between the first three weeks and last three weeks of the study period $(\mathrm{t}=0.356$, $\mathrm{df}=4, \mathrm{P}=0.740)$. Chronological occupancy data was not available for comparison from the 2000/2001 study period. The first observed hatched chick was recorded on 8 July 2018, confirming that the study spanned peak laying period. 
Table 2. Breeding pair estimates and annual population rates of change for Leach's Storm-Petrels (Hydrobates leucorhous) nesting on Kent Island, New Brunswick from 2001 to 2018.

\begin{tabular}{lccc}
\hline \hline Location & Year & Breeding Pair Estimate (95\% CI) & Annual Change 2001-2018 (95\% CI) \\
\hline North & 2001 & 24,881 & $-2.48 \%$ \\
& 2018 & $(19,239-30,524)$ & $(-4.10 \%$ to $-0.47 \%)$ \\
& 2001 & 16,245 & $+1.03 \%$ \\
South & & $(12,214-20,275)$ & $(-3.54 \%$ to $7.91 \%)$ \\
& 2018 & 4535 & $-1.79 \%$ \\
Entire Island & 2001 & $(1512-7558)$ & $(-3.28 \%$ to $-0.25 \%)$ \\
& 2018 & $29398-716$ & \\
\end{tabular}

\section{Breeding pair estimates}

Based on the occupied burrow densities and total area surveyed for each region of the island in 2000/2001, breeding pair estimates (mean \pm SE) of $24,881 \pm 2879$ (CI 19,239-30,524) and 4535 \pm 1542 (CI 1511-7558) were calculated for the north and south regions of Kent Island respectively, with a total estimate of 29,416 \pm 3266 (CI 23,015-35,817) breeding pairs for the entire colony (Table 2).

In 2018 , breeding pair estimates (mean \pm SE) of $16,245 \pm 2056$ (CI 12,214-20,275) and $5398 \pm 1239$ (CI 2980-7817) were calculated for the north and south regions of Kent Island, respectively, with a total of $21,643 \pm 2398$ (CI 16,943-26,343) breeding pairs for the entire colony (Table 2).

From 2000/2001 to 2018, the population has not shown significant evidence of change in the south $(\mathrm{t}=0.441 ; \mathrm{df}=506 ; \mathrm{P}=0.660)$ with an annual rate of change of $1.03 \%$ and has decreased significantly in the north $(\mathrm{t}=1.963 ; \mathrm{df}=1192 ; \mathrm{P}=0.0498)$ and for the entire island $(\mathrm{t}=2.506 ; \mathrm{df}=684 ; \mathrm{P}=0.0124)$, with annual rates of change of $-2.48 \%$ and $-1.79 \%$, respectively (Table 2 ).

\section{Evidence of predation}

Evidence of predation on storm-petrels found in plots in 2018 included the following: 14 carcasses, 31 instances of pairs or single wings, 18 feather piles, and a broken egg. In the southern region of the island, $6.9 \%$ of all plots surveyed contained evidence of predation, while $10.1 \%$ of all plots in the northern region of the island contained evidence of predation, with $8.7 \%$ of plots on the entire island containing evidence of predation. Occurrence of signs of predation differed significantly among habitat types $\left(\mathrm{X}^{2}\right.$ $=14.09, \mathrm{df}=6, \mathrm{P}<0.05$; Table 3$)$. Mean $( \pm \mathrm{SE})$ number of gull nests observed within $10 \mathrm{~m}$ of plots in 2018 were $0.266 \pm 0.05$ and $1.23 \pm 0.09$ in the northern and southern regions of the island, respectively.

\section{Nest site use}

All 2000/2001 and 2018 survey plots were used to create three CART models in order to investigate nest site use by storm-petrels. Occupied burrow presence, occupied burrow density and occupancy rate were the response variables respectively for each separate model (Table 4).
In 2000/2001, presence of occupied burrows was primarily influenced by dominant canopy type $(\mathrm{P}<0.001)$, with ash, birch, and fir being preferred and secondarily influenced by the presence of deadfall (Table 4, $\mathrm{P}=0.017$ ). Occupied burrow densities were primarily influenced by dominant understory type $(\mathrm{P}<0.001)$, with fern being preferred over aster, goldenrod, grass, moss, and shrub/bramble (Table 4, Fig. 2).

Table 3. Percentage of plots by habitat type with evidence of predation upon Leach's Storm-petrels (Hydrobates leucorhous) nesting on Kent Island, New Brunswick in 2018.

\begin{tabular}{lcc}
\hline \hline Habitat & $\begin{array}{c}\text { Plots with } \\
\text { Evidence of } \\
\text { Predation (\%) }\end{array}$ & Number of Plots \\
\hline Shrub / Bramble & $12.50 \%$ & 128 \\
Fern & $12.10 \%$ & 83 \\
Forest & $10.30 \%$ & 261 \\
Goldenrod & $8.30 \%$ & 12 \\
Miscellaneous Low Vegetation & $8.30 \%$ & 12 \\
Grass & $2.20 \%$ & 179 \\
Moss & $0.00 \%$ & 3 \\
\hline
\end{tabular}

In 2018, occupied burrows were more likely to be found in plots with fern or shrub/bramble as the dominant understory ( $\mathrm{P}=$ 0.001), which also had no gull nests nearby $(P=0.009)$ and no forest regrowth (Table 3; $\mathrm{P}=0.009$ ). The density of occupied burrows was primarily influenced by dominant understory $(\mathrm{P}=$ $0.024)$, where fern- and shrub/bramble-dominated plots had greater densities than plots dominated by grass, miscellaneous low vegetation, goldenrod, aster, or moss (Table 4, Fig. 2). CART models failed to find occupancy rate to be associated with any of the predictor variables for either $2000 / 2001$ or 2018 .

To analyze how nest site use might vary within the two regions of the island, additional CART analyses were run separately for the north and south areas for 2000/2001 and 2018. In the north in 2000/2001, occupied burrow presence was highest where the dominant understory was fern dominated $(\mathrm{P}=0.04)$ and occupied burrow densities were highest where the understory was goldenrod or fern dominated $(P=0.004)$. In 2018, occupied burrow presence was greatest where there was no forest regrowth 
Table 4. Habitat preferences for Leach's Storm-Petrels (Hydrobates leucorhous) nesting on Kent Island, New Brunswick in 2000/2001 and 2018. Classification and regression tree (CART) analysis was used to determine which habitat variables greatly influenced nest site utilization based on occupied/unoccupied burrows and burrow densities. CART failed to find any predictors of occupancy rates; thus, results were omitted from the table. Habitat variables considered in each model included dominant canopy, dominant understory, canopy closure, soil moisture, signs of forest regrowth, and the number of gull nests nearby plots. See methods for full list of canopy and understory types.

\begin{tabular}{llll}
\hline \hline Dependent Variable & Year & Primary Variable & Secondary Variable \\
\hline Occupied Burrow Presence & $2000 / 2001$ & Dominant Canopy (ash, birch, fir) & Tertiary Variable \\
& 2018 & Dominant Understory (fern, shrub/bramble) & Gull Nests Nearby < 1 \\
Occupied Burrow Density & $2000 / 2001$ & Dominant Understory (fern) & Forest Regrowth (No) \\
& 2018 & Dominant Understory (fern, shrub/bramble) & \\
\hline
\end{tabular}

Fig. 2. Mean occupied burrow densities per dominant canopy and dominant understory vegetation type of Leach's StormPetrels (Hydrobates leucorhous) nesting on Kent Island, New Brunswick. Open circles represent the 2001 study period and open triangles represent the 2018 study period. Error bars represent the standard error.

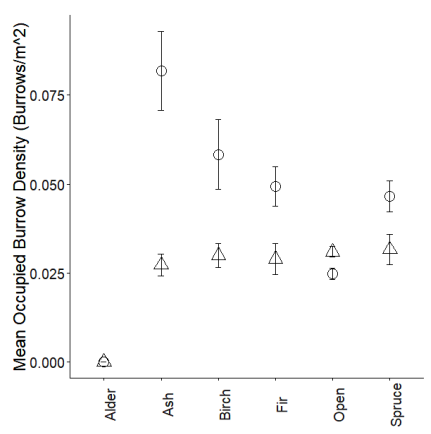

Dominant Canopy

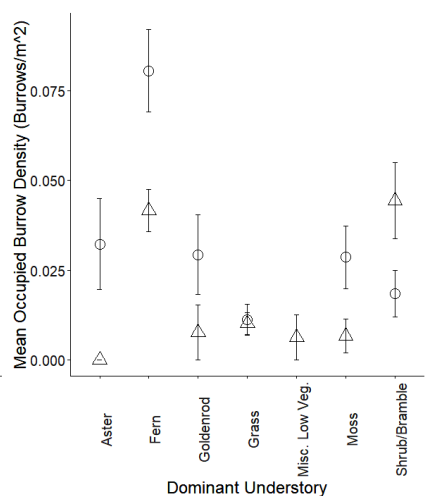

Dominant Understory
$(P=0.012)$, while regression trees failed to classify occupied burrow densities. In the south, regression trees failed to classify any of the dependent variables in both study periods.

\section{DISCUSSION}

Though small in comparison with more northern storm-petrel colonies in Atlantic Canada (Wilhelm et al. 2015, 2019), the Kent Island population currently represents one of the two largest colonies (Pollet and Shutler 2018) south of Newfoundland, and the largest colony in the province of New Brunswick. This study documents a substantial decline across a span of 17 years when many other colonies across Atlantic Canada have observed precipitous declines (Robertson et al. 2006, Wilhelm et al. 2015, 2019, Pollet and Shutler 2018). Census work resulted in an estimate for the entire colony of 29,416 breeding pairs in $2000 / 2001$ and 21,643 breeding pairs in 2018. The difference between these totals represents a $26.4 \%$ total decline and $1.79 \%$ annual decline for the colony since 2000/2001. Macrohabitat characteristics influenced nest site use of storm-petrels on the island, with nesting density varying with habitat characteristics and predator presence across the island (Fig. 2, Table 4).

\section{Breeding population status and trend}

Occupied burrow densities at other storm-petrel colonies across Atlantic Canada range widely, from 0.017 to 1.97 burrows $/ \mathrm{m}^{2}$ (Robertson et al. 2006, Wilhelm et al. 2015, 2019). Thus, the occupied burrow densities observed in the south and north of Kent Island in both 2000/2001 (0.015 and 0.061, respectively) and 2018 ( 0.018 and 0.040 , respectively) are near the low end of this range. Occupancy rates across the region range from 0.34 to over 0.8 , with Kent Island falling in the midrange. The nearest of Atlantic Canada's major Leach's Storm-Petrel colonies, Bon Portage Island in southwestern Nova Scotia, had a mean occupied burrow density of 0.08 burrows $/ \mathrm{m}^{2}$ and an overall burrow occupancy rate of 0.56 as of 2017 (Pollet and Shutler 2018). Though occupied burrow density was considerably higher on Bon Portage Island compared to Kent Island, the colonies faced similar declines in occupied burrow densities over an almost identical period.

Population trends varied in the different regions of the island, with the primarily open habitat of the southern region of the island experiencing an annual increase of $1.03 \%$ and the primarily forested northern region of the island suffering an annual decline of $2.48 \%$ since $2000 / 2001$. The population trend for the entire island over a similar period echoes the $1.33 \%$ annual rate of decline and $20 \%$ total population decline over 16 years observed on nearby Bon Portage Island (Pollet and Shutler 2018). The annual rate of decline observed in the predominantly forested northern region aligns closely with annual rates of change observed in open habitat in a major Newfoundland colony (Stenhouse and Montevecchi 1999, Wilhelm et al. 2015). Moreover, declines observed over the past $\sim 30$ years at the largest colony for this species (Baccalieu Island, Newfoundland and Labrador) show annual rates of decline of $1.4 \%$ per year and the largest declines were observed in forested habitats (Wilhelm et al. 2019), similar to our results on Kent Island. Given these similar declines among multiple colonies and the very high nest-site fidelity observed with this species (Pollet et al. 2019), dispersal is an unlikely mechanism for the decreasing population on Kent Island. Therefore, our results are consistent with the growing body of evidence suggesting a region-wide decline, even though there may be different local habitat and predation stressors acting within and among these colonies.

One possible external contributor to regional population trends for this species is elevated mercury $(\mathrm{Hg})$ levels, relative to other seabirds breeding in Atlantic Canada (Goodale et al. 2008). For 
example, Common Loons (Gavia immer) have been found to experience declines in reproductive success when blood $\mathrm{Hg}$ concentrations reach a threshold of $3 \mu \mathrm{g} / \mathrm{g}$ wet wt. (Burgess and Meyer 2008). Blood $\mathrm{Hg}$ concentrations of storm-petrels within the Gulf of Maine region have been found to remain well below this threshold, suggesting that storm-petrels in the region may not reach a threshold where reproductive success is impacted (Bond and Diamond 2009, Pollet et al. 2017). Additionally, mercury loads in storm-petrels have shown wide variation across their breeding range, with Kent Island birds showing lower mercury loads than colonies in Newfoundland (Burgess, Hedd, Pollet et al. 2019, unpublished data). Thus, the effects of industrial contaminants, i.e., mercury, on population declines at Kent Island and other Atlantic Canadian colonies remains uncertain and warrants further investigation. Another potential cause for declining population trends is strandings associated with light pollution from the offshore oil and gas industry (Wiese et al. 2001, Montevecchi 2006, Ronconi et al. 2015). However, foraging ranges of storm-petrels nesting at colonies located in northern Nova Scotia and the east coast of Newfoundland overlap with offshore oil and gas platforms, yet the foraging range of Kent Island storm-petrels does not (Hedd et al. 2018), suggesting that this source of potential mortality is not a factor for the Kent island colony. Chronic oil spills within seabird foraging ranges also pose risk of increased mortality (Wiese and Robertson 2004). European Storm-Petrels (Hydrobates pelagicus) have demonstrated decreased reproductive investment due to acute oil pollution (Zabala et al. 2011), thus chronic spills within storm-petrel foraging ranges may further impact populations. Within the Bay of Fundy region, other seabird species have been shown to be at increased risk of oiling from chronic oil pollution (Lieske et al. 2014). Assessment of cumulative risks to breeding seabirds, including risk of oiling, show areas of high vulnerability in the lower Bay of Fundy, and Leach's Storm-petrels rank among the highest in terms of species aggregate vulnerability across Atlantic Canada (Lieske et al., in press).

Another stressor of utmost concern not only for Kent Island, but all colonies, are the effects of climate change on storm-petrel feeding ecology and reproductive success, as increasing mean global sea and air temperatures over a multidecadal timescale have shown negative effects on hatching success (Mauck et al. 2018). However, with other broad scale issues such as oil and gas industry impacts and mercury contamination likely playing a lesser role for the population trend of the colony on Kent Island, we must, therefore, consider fine-scale issues such as habitat suitability and predation pressure that may be influencing population dynamics from stressors within the colony.

\section{Influence of habitat on nest site use}

Habitat suitability can have profound effects on the nesting distribution and population trends of several burrowing Procellariform species (Stenhouse and Montevecchi 2000, Brodier et al. 2011, Shaw et al. 2011). In 2000/2001, Leach's Storm-Petrels on Kent Island were more likely to be nesting in forested regions (ash, birch, fir) where deadfall was present, and in greater densities where the dominant understory was fern. In 2018, storm-petrels were more likely to be nesting and in greater densities where the dominant vegetation was fern or shrub/ bramble and where there were no signs of forest regrowth. A decline in both occupied and total burrow densities occurred in the predominantly forested north and a slight increase occurred in the predominantly open habitat of the south. Despite the decline in the north, the highest occupied burrow densities $(0.091$ \pm 0.02 burrows $/ \mathrm{m}^{2}$ ) on the island were observed in the open habitat (fern, grass, shrub/bramble) of the north. This shift in preference of habitat from forest to open found in our study contrasts with other research showing that storm-petrels nest at greater densities in forested habitat as compared to open habitat (Stenhouse and Montevecchi 2000, Robertson et al. 2006, Wilhelm et al. 2015), although recent census work on Baccalieu Island has shown dramatic declines in the number of storm-petrels nesting in forest as well (Wilhelm et al. 2019). As burrow densities are directly correlated to the suitability of habitat for storm-petrel nesting (Robertson et al. 2006), these results suggest that changes in suitable habitat may have occurred.

There are a few possible explanations for these differing population trends and potential changes in habitat suitability across the island. One cause for declining burrow densities and population size in the forest could be forest regrowth. The 2007 eradication of snowshoe hares allowed saplings and immature trees to crowd the forest floor and surface soil (Wheelwright 2016), potentially compromising the structure of pre-existing burrows, as well as making it more difficult for storm-petrels to excavate new burrows in the short term. Our results suggest that the removal of invasive hares from the island has potentially had adverse effects on the nesting capabilities of storm-petrels. This contradicts previous studies where the eradication of hares resulted in increased habitat suitability for burrow nesting Procellariforms (Priddel et al. 2000, Brodier et al. 2011). However, a storm-petrel colony on Great Duck Island in nearby Maine has either remained stable or increased despite the continuing presence of invasive hares (P Shannon, personal communication). Additionally, eradications of invasive European rabbits (Oryctolagus cuniculus) on other seabird colonies have shown minimal positive effects on population sizes of other storm-petrel species (Campos and Granadeiro 1999, Bried and Neves 2015). With only two sampling periods straddling the eradication of hares on Kent Island, it is difficult to ascertain the effects (either positive or negative) of hare removal and vegetation regrowth on Leach's Strom-petrels. Continued monitoring of specific sites experiencing forest regeneration may better quantify the benefits or impacts of hare removal in the short and long term.

Another potential cause for the changes in burrow densities in the north since the last census is the 2008 outbreak of bark beetles, which decimated much of the island's mature spruce forest (Wheelwright 2016). These outbreaks can significantly increase soil moisture, as the removal of mature trees alters water cycling processes (Reed et al. 2018). Such an increase in soil moisture can create less favorable nesting conditions and decreased hatching success for burrow nesting petrels (Schramm 1986, Carter 1997). Although soil moisture was not associated with nest site selection in this study, storm-petrels on the island have previously shown preference for nesting in burrows with low soil moisture and have been known to relocate to another burrow if their nest site becomes saturated (Fricke et al. 2015). This could account for the observed increase in the number of storm-petrels nesting in the predominantly open southern half of the island and give a partial explanation for the decline observed in the predominantly 
forested north. Thus, relationships between soil moisture and nest site suitability on Kent Island (Fricke et al. 2015), and ultimately potential effects on population size or redistribution within the colony, warrant further investigation as the forest continues to regenerate following the eradication of hares and the recovery after the bark beetle infestation.

\section{Influence of predation on nest site use}

Gulls prey on storm-petrels in Atlantic Canada, sometimes killing thousands of individuals at colonies during a single breeding season (Stenhouse et al. 2000, Robertson et al. 2006). Therefore, their presence could affect nest site use and population dynamics. In this study, the presence of gull nests within $10 \mathrm{~m}$ of a survey plot was negatively associated with the presence, but not density, of nesting storm-petrels. This result suggests that gull presence is an active influence upon where storm-petrels dig their nest burrows but has little effect on the overall number of storm-petrels nesting in any given area. Recent findings show that the population of Herring Gulls on Kent Island has decreased by $36 \%$ since 2001 (Bennett et al. 2017) and a decrease in predation pressure might have occurred as a result. Declines in prey availability have resulted in increased predatory efforts toward smaller seabird species and decreased breeding success in gulls (Regehr and Montevecchi 1997, Stenhouse and Montevecchi 1999). However, declining gull populations could result in less competition over resources and an associated increase in productivity or breeding success (e.g., Bennett et al. 2017), which may result in decreased predation on storm-petrels, but these dynamics between predator-prey relationships for conesting seabirds remain poorly known.

Despite the uneven distribution of gulls around the island with most gulls occurring in large patches in the south (Fig. 1d), instances of predation occurred at similarly low rates across the island, with $10.1 \%$ of plots in the north and $6.9 \%$ of plots in the south showing signs of predation. However, occurrence of predation varied significantly across habitat types, with occurrences being lower in grass dominated plots, though this could be attributed to lower burrow densities occurring in grass dominated plots compared to the island's other habitat types. Perhaps then, storm-petrels on the island are preferentially nesting in areas of low gull nesting densities not only because of predation pressure, but also because of interspecific competition for nesting habitat. Interspecific nest site competition has been documented in other burrowing seabird species (Ramos et al. 1997, Sullivan et al. 2000), and larger burrowing seabirds have been known to outcompete storm-petrels for nest sites (McClelland et al. 2008, Sato et al. 2010). Though little is known regarding any potential interspecific nest site competition between gulls and storm-petrels, previous work has shown that high densities of surface nesting Great Cormorants (Phalacrocorax carbo) resulted in decreased habitat suitability for European Storm-Petrels because of trampling of vegetation and resultant soil erosion (Cadiou et al. 2010). Therefore, presence and/or high densities of surface nesting gulls may displace stormpetrels from potential burrowing sites. Alternatively, habitat requirements between species may differ enough to limit cooccurrence.

In addition to gulls, storm-petrel feathers and a wing were found near a river otter den in 2018, providing evidence of otter predation on storm-petrels that may pose a new predatory threat for the colony. Past studies of river otter predation upon stormpetrels have shown that occurrences happen regularly and may pose a risk to smaller storm-petrel colonies with low burrow densities (Quinlan 1983, Speich and Pitman 1984). However, otter predation likely poses a very minor threat for a colony of Kent Island's magnitude.

\section{Future directions}

With the Atlantic Canadian population of storm-petrels in steep decline, it is increasingly important to monitor population trends of major colonies. Though the breeding population on Kent Island has undergone a significant decline over a 17 year span, it is likely that census work for the island only reasonably needs to be conducted every 10 or so years to avoid high levels of disturbance. However, it may be beneficial to create permanent plots within various habitat types across the island that can be monitored more frequently in order to assess if changes in habitat are in fact drivers of changing burrow densities and population trends. If population levels and burrow densities begin to increase as the forest continues to grow and mature, hare eradications could then be recommended for other colonies to promote longterm population growth and stability. Gull predation should also be monitored at the colony because increased predation on stormpetrels by gulls might be expected to occur because of forage fish availability and distribution fluctuations associated with changing oceanic climate (Stenhouse and Montevecchi 1999, Buren et al. 2012).

Responses to this article can be read online at: http://www.ace-eco.org/issues/responses.php/1526

\section{Acknowledgments:}

We thank Patty Jones and Ian Kyle of the Bowdoin Scientific Station for accommodations and logistical support, Greg Robertson for lending his expertise with population trend analysis, Laura McFarlane-Tranquilla for her guidance both in the field and beyond, Bill Montevecchi and three anonymous reviewers for their comments on the manuscript, the Leonard Lab at Dalhousie University for their support and guidance, as well as the entire Kent Island field crew. This study was supported by funding provided by Environment and Climate Change Canada through an Atlantic Ecosystems Initiatives grant to Bird Studies Canada and a grant from the New Brunswick Wildlife Trust Fund. Finally, we would like to dedicate this paper to the late Chuck Huntington who devoted much of his life to the study of the Leach's Storm-Petrels who call Kent Island home.

\section{LITERATURE CITED}

Ainley, D. G., W. McIver, J. Adams, and M. Parker. 2019. Ashy Storm-Petrel Oceanodroma homochroa, version 2.0. In P. G. Rodewald, editor. The birds of North America. Cornell Lab of Ornithology, Ithaca, New York, USA. https://doi.org/10.2173/ bna. 185

Anderson, O. R. J., C. J. Small, J. P. Croxall, E. K. Dunn, B. J. Sullivan, O. Yates, and A. Black. 2011. Global seabird bycatch in 
longline fisheries. Endangered Species Research 14:91-106. https:// doi.org/10.3354/esr00347

Bennett, J. L., E. G. Jamieson, R. A. Ronconi, and S. N. P. Wong. 2017. Variability in egg size and population declines of Herring Gulls in relation to fisheries and climate conditions. Avian Conservation and Ecology 12(2):16. https://doi.org/10.5751/ ACE-01118-120216

BirdLife International. 2018. Hydrobates leucorhous. The IUCN Red List of Threatened Species. 2018:e.T132438298A132438484. https://dx.doi.org/10.2305/IUCN.UK.2018-2.RLTS. T132438298A132438484.en.

Bond, A. L., and A. W. Diamond. 2009. Mercury concentrations in seabird tissues from machias Seal Island, New Brunswick, Canada. Science of the Total Environment 407:4340-4347. https:// doi.org/10.1016/j.scitotenv.2009.04.018

Bried, J., and V. Neves. 2015. Habitat restoration on Praia Islet, Azores Archipelago, proved successful for seabirds, but new threats have emerged. Airo 23:25-35.

Brodier, S., B. Pisanu, A. Villers, E. Pettex, M. Lioret, J.-L. Chapuis, and V. Bretagnolle. 2011. Responses of seabirds to the rabbit eradication on Ile Verte, sub-Antarctic Kerguelen Archipelago. Animal Conservation 14(5):459-465. https://doi. org/10.1111/j.1469-1795.2011.00455.x

Buren, A. D., M. Koen-Alonso, and W. A. Montevecchi. 2012. Linking predator diet and prey availability: Common Murres and capelin in the Northwest Atlantic. Marine Ecology Progress Series 445:25-35. https://doi.org/10.3354/meps09465

Burgess, N. M., and M. W. Meyer. 2008. Methylmercury exposure associated with reduced productivity in Common Loons. Ecotoxicology 17:83-91. https://doi.org/10.1007/s10646-007-0167-8

Cadiou, B., F. Bioret, and D. Chenesseau. 2010. Response of breeding European Storm-Petrels Hydrobates pelagicus to habitat change. Journal of Ornithology 151:317-327. https://doi. org/10.1007/s10336-009-0458-3

Campos, A. R., and J. P. Granadeiro. 1999. Breeding biology of the White-Faced Storm-Petrel on Selvagem Grande Island, North-East Atlantic. Waterbirds 22(2):199-206. https://doi. org/10.2307/1522208

Cannell, P. F., and G. D. Maddox. 1983. Population change in three species of seabirds at Kent Island, New Brunswick. Journal of Field Ornithology 54:29-35. [online] URL: https://www.jstor. org/stable/4512784

Carter, J. 1997. Nest site selection and breeding success of Wedgetailed Shearwaters Puffinus pacificus at Heron Island. Australian Geographical Studies 35:153-167. https://doi.org/10.1111/1467-8470.00016

Catry, P., A. Campos, P. Segurado, M. Silva, and I. Strange. 2003. Population census and nesting habitat selection of Thin-billed Prion Pachyptila belcheri on New Island, Falkland Islands. Polar Biology 26:202-207. https://doi.org/10.1007/s00300-002-0465-9

Clark, W. R., R. A. Schmitz, and T. R. Bogenschutz. 1999. Site selection and nest success of Ring-Necked Pheasants as a function of location in Iowa. Journal of Wildlife Management 63:976-989. https://doi.org/10.2307/3802812
Croxall, J. P., P. N. Trathan, and E. J. Murphy. 2002. Environmental change and Antarctic seabird populations. Science 297(5586):1510-1514. https://doi.org/10.1126/science.1071987

Cury, P. M., I. L. Boyd, S. Bonhommeau, T. Anker-Nilssen, R. J. M. Crawford, R. W. Furness, J. A. Mills, E. J. Murphy, H. Österblom, M. Paleczny, J. F. Piatt, J.-P. Roux, L. Shannon, and W. J. Sydeman. 2011. Global seabird response to forage fish depletion - one-third for the birds. Science 334(6063):1703-1706. https://doi.org/10.1126/science.1212928

Danchin, E., T. Boulinier, and M. Massot. 1998. Conspecific reproductive success and breeding habitat selection: implications for the study of coloniality. Ecology 79(7):2415-2428. https://doi. org/10.1890/0012-9658(1998)079[2415:CRSABH]2.0.CO;2

Davoren, G. K., and W. A. Montevecchi. 2003. Signals from seabirds indicate changing biology of capelin stocks. Marine Ecology Progress Series 258:253-261. https://doi.org/10.3354/ meps 258253

De'ath, G., and K. E. Fabricius. 2000. Classification and regression trees: a powerful yet simple technique for ecological data analysis. Ecology 81:3178-3192. https://doi.org/10.1890/0012-9658 (2000)081[3178:CARTAP]2.0.CO;2

Fretwell, S. D., and H. L. Lucas. 1969. On territorial behavior and other factors influencing habitat distribution in birds. Acta Biotheoretica 19:16-36. https://doi.org/10.1007/bf01601953

Fricke, E. C., K. M. Blizzard, D. P. Gannon, and R. A. Mauck. 2015. Model of burrow selection predicts pattern of burrow switching by Leach's Storm-Petrels. Journal of Field Ornithology 86(4):326-336. https://doi.org/10.1111/jofo.12126

Goodale, M. W., D. C. Evers, S. E. Mierzykowski, A. L. Bond, N. M. Burgess, C. I. Otorowski, L. J. Welch, C. S. Hall, J. C. Ellis, R. B. Allen, A. W. Diamond, S. W. Kress, and R. J. Taylor. 2008. Marine foraging birds as bioindicators of mercury in the Gulf of Maine. EcoHealth 5:409-425. https://doi.org/10.1007/s10393-009-0211-7

Goyert, H. F., E. O. Garton, and A. J. Poe. 2018. Effects of climate change and environmental variability on the carrying capacity of Alaskan seabird populations. Auk 135:975-991. https://doi. org/10.1642/AUK-18-37.1

Gross, W. A. O. 1935. The life history cycle of Leach's Petrel (Oceanodroma leucorhoa leucorhoa) on the outer sea islands of the Bay of Fundy. Auk 52:383-399. https://doi.org/10.2307/4077511

Guisan, A., and N. E. Zimmerman. 2000. Predictive habitat distribution models in ecology. Ecological Modelling 135:147-186. https://doi.org/10.1016/S0304-3800(00)00354-9

Hedd, A., I. L. Pollet, R. A. Mauck, C. M. Burke, M. L. Mallory, L. A. McFarlane Tranquilla, W. A. Montevecchi, G. J. Robertson, R. A. Ronconi, D. Shutler, S. I. Wilhelm, and N. M. Burgess. 2018. Foraging areas, offshore habitat use, and colony overlap by incubating Leach's Storm-Petrels Oceanodroma leucorhoa in the Northwest Atlantic. PLoS ONE 13(5):e0194389. https://doi. org/10.1371/journal.pone.0194389

Hipfner, J. M., M. J. F. Lemon, and M. S. Rodway. 2010. Introduced mammals, vegetation changes and seabird conservation on the Scott Islands, British Columbia, Canada. 
Bird Conservation International 20:295-305. https://doi. org/10.1017/S0959270910000043

Hothorn, T., K. Hornik, and A. Zeileis. 2006. Unbiased recursive partitioning: a conditional inference framework. Journal of Computational and Graphical Statistics 15:651-674. https://doi. org/10.1198/106186006X133933

Lieske D. J., D. A. Fifield, and C. Gjerdrum. 2014. Maps, models, and marine vulnerability: assessing the community distribution of seabirds at-sea. Biological Conservation 172:15-28. http://dx. doi.org/10.1016/j.biocon.2014.02.010

Lieske, D. J., L. McFarlane Tranquilla, R. A. Ronconi, and S. Abbott. In press. Seas of risks: assessing the threats to colonialnesting seabirds in Eastern Canada. Marine Policy. https://doi. org/10.1016/j.marpol.2020.103863

Maslo, B., S. N. Handel, and T. Pover. 2011. Restoring beaches for Atlantic Coast Piping Plovers (Charadrius melodus): a classification and regression tree analysis of nest site selection. Restoration Ecology 19(201):194-203. https://doi.org/10.1111/ j.1526-100X.2010.00709.x

Mauck, R. A., D. C. Dearborn, and C. E. Huntington. 2018. Annual global mean temperature explains reproductive success in a marine vertebrate from 1955 to 2010. Global Change Biology 24:1599-1613. https://doi.org/10.1111/gcb.13982

McClelland, G. T. W., I. L. Jones, J. L. Lavers, and F. Sato. 2008. Breeding biology of Tristram's Storm-Petrel Oceanodroma tristrami at French Frigate Shoals and Laysan Island, Northwest Hawaiian Islands. Marine Ornithology 36:175-181. [online] URL: http://www.marineornithology.org/PDF/36_2/36_2_175-181.pdf

Montevecchi, W. A. 2006. Influences of artificial light on marine birds. Pages 94-113 in C. Rich and T. Longcore, editors. Ecological consequences of artificial night lighting. Island, Washington, D. C., USA.

Oliveira, N. 2016. Status report for Monteiro's Storm-Petrel Hydrobates monteiroi. Sociedade Portuguesa para o Estudo das Aves, Lisboa, Portugal.

Piatt, J. F., W. J. Sydeman, and F. Wiese. 2007. Seabirds as indicators of marine ecosystems. Marine Ecology Progress Series 352:199-204. https://doi.org/10.3354/meps07070

Pollet, I. L., A. L. Bond, A. Hedd, C. E. Huntington, R. G. Butler, and R. Mauck. 2019. Leach's Storm-Petrel (Oceanodroma leucorhoa), version 2.0. In P. G. Rodewald, editor. The birds of North America. Cornell Lab of Ornithology, Ithaca, New York, USA. https://doi.org/10.2173/bna.lcspet.02

Pollet, I. L., M. L. Leonard, N. J. O'Driscoll, N. M. Burgess, and D. Shutler. 2017. Relationships between blood mercury levels, reproduction, and return rate in a small seabird. Ecotoxicology 26:97-103. https://doi.org/10.1007/s10646-016-1745-4

Pollet, I. L., and D. Shutler. 2018. Leach's Storm-Petrel population trends on Bon Portage Island, Canada. Seabird $31: 75-83$

Priddel, D., N. Carlile, and R. Wheeler. 2000. Eradication of European rabbits (Oryctolagus cuniculus) from Cabbage Tree Island, NSW, Australia, to protect the breeding habitat of Gould's
Petrel (Pterodroma leucoptera leucoptera). Biological Conservation 94:115-125. https://doi.org/10.1016/S0006-3207(99)00155-X

Provencher, J. F., A. L. Bond, A. Hedd, W. A. Montevecchi, S. Bin Muzaffar, S. J. Courchesne, H. G. Gilchrist, S. E. Jamieson, F. R. Merkel, K. Falk, J. Durinck, and M. L. Mallory. 2014. Prevalence of marine debris in marine birds from the North Atlantic. Marine Pollution Bulletin 84:411-417. https://doi. org/10.1016/j.marpolbul.2014.04.044

Quinlan, S. E. 1983. Avian and river otter predation in a stormpetrel colony. Journal of Wildlife Management 47(4):1036-1043. https://doi.org/10.2307/3808162

R Core Team. 2018. R: A language and environment for statistical computing. R Foundation for Statistical Computing, Vienna, Austria. [online] URL: https://www.R-project.org/

Ramos, J. A., L. R. Monteiro, E. Sola, and Z. Moniz. 1997. Characteristics and competition for nest cavities in burrowing Procellariiformes. Condor 99:634-641. https://doi.org/10.2307/1370475

Reed, D. E., B. E. Ewers, E. Pendall, J. Frank, and R. Kelly. 2018. Bark beetle-induced tree mortality alters stand energy budgets due to water budget changes. Theoretical and Applied Climatology 131:153-165. https://doi.org/10.1007/s00704-016-1965-9

Regehr, H. M., and W. A. Montevecchi. 1997. Interactive effects of food shortage and predation on breeding failure of Blacklegged Kittiwakes: indirect effects of fisheries activities and implications for indicator species. Marine Ecology Progress Series 155:249-260. https://doi.org/10.3354/meps155249

Robertson, G. J., J. Russel, R. Bryant, D. A. Fifield, and I. J. Stenhouse. 2006. Size and trends of Leach's Storm-Petrel Oceanodroma leucorhoa breeding populations in Newfoundland. Atlantic Seabirds 8:41-50.

Rodríguez, A., J. M. Arcos, V. Bretagnolle, M. P. Dias, N. D. Holmes, M. Louzao, J. Provencher, A. F. Raine, F. Ramirez, B. Rodríguez, R. A. Ronconi, R. S. Taylor, E. Bonnaud, S. B. Borrelle, V. Cortés, V. Descamps, V. L. Friesen, M. Genovart, A. Hedd, P. Hodum, G. R. W. Humphries, M. Le Corre, C. Lebarbenchon, R. Martin, E. F. Melvin, W. A. Montevecchi, P Pinet, I. L. Pollet, R. Ramos, J. C. Russell, P. G. Ryan, A. SanzAguilar, D. R. Spatz, M. Travers, S. C. Votier, R. M. Wanless, E. Woehler, and A. Chiaradia. 2019. Future directions in conservation research on petrels and shearwaters. Frontiers in Marine Science 6:94. https://doi.org/10.3389/fmars.2019.00094

Ronconi, R. A., K. A. Allard, and P. D. Taylor. 2015. Bird interactions with offshore oil and gas platforms: review of impacts and monitoring techniques. Journal of Environmental Management 147:34-45. https://doi.org/10.1016/j.jenvman.2014.07.031

Ronconi, R. A., and S. N. P. Wong. 2003. Estimates of changes in seabird numbers in the Grand Manan Archipelago, New Brunswick, Canada. Waterbirds 26:462-472. https://doi. org/10.1675/1524-4695(2003)026[0462:EOCISN]2.0.CO;2

Sato, F., K. Karino, A. Oshiro, H. Sugawa, and M. Hirai. 2010. Breeding of Swinhoe's Storm-Petrel Oceanodroma monorhis in the Kutsujima Islands, Kyoto, Japan. Marine Ornithology 38:133-136. [online] URL: https://www.marineornithology.org/ content/get.cgi?rn=899 
Avian Conservation and Ecology 15(1): 11

Schjørring, S., J. Gregersen, and T. Bregnballe. 2000. Sex difference in criteria determining fidelity towards breeding sites in the Great Cormorant. Journal of Animal Ecology 69:214-223. https://doi.org/10.1046/j.1365-2656.2000.00385.x

Schramm, M. 1986. Burrow densities and nest site preferences of petrels (Procellariidae) at the Prince Edward Islands. Polar Biology 6:63-70. https://doi.org/10.1007/BF00258254

Shaw, J., A. Terauds, and D. Bergstrom. 2011. Rapid commencement of ecosystem recovery following aerial baiting on sub-Antarctic Macquarie Island. Ecological Management and Restoration 12:241-244. https://doi.org/10.1111/j.1442-8903.2011.00611. $\mathrm{x}$

Speich, S. M., and R. L. Pitman. 1984. River otter occurrence and predation on nesting marine birds in the Washington Islands Wilderness. Murrelet 65(1):25-27. https://doi.org/10.2307/3534208

Steenweg, R. J., R. A. Ronconi, and M. L. Leonard. 2011. Seasonal and age-dependent dietary partitioning between the Great Black-backed and Herring Gulls. Condor 113:795-805. https://doi.org/10.1525/cond.2011.110004

Stenhouse, I. J., and W. A. Montevecchi. 1999. Indirect effects of the availability of capelin and fishery discards: gull predation on breeding storm-petrels. Marine Ecology Progress Series 184:303-307. https://doi.org/10.3354/meps184303

Stenhouse, I. J., and W. A. Montevecchi. 2000. Habitat utilization and breeding success in Leach's Storm-Petrel: the importance of sociality. Canadian Journal of Zoology 78:1267-1274. https://doi. org/10.1139/z00-065

Stenhouse, I. J., G. J. Robertson, and W. A. Montevecchi. 2000. Herring Gull Larus argentatus predation on Leach's StormPetrels Oceanodroma leucorhoa breeding on Great Island, Newfoundland. Atlantic Seabirds 2:35-44.

Sullivan, W. J., K. J. Wilson, and A. Paterson. 2000. Influence of artificial burrows and microhabitat on burrow competition between Chatham Petrels Pterodroma axillaris and Broad-billed Prions Pachyptila vittata. Emu Austral Ornithology 100:329-333. https://doi.org/10.1071/MU00058

Wheelwright, N. T. 2016. Eradication of an ecosystem engineer. Frontiers in Ecology and the Environment 14(1):53-54. https://doi. org/10.1002/fee. 1221

Wiese, F. K., W. A. Montevecchi, G. K. Davoren, F. Huettmann, A. W. Diamond, and J. Linke. 2001. Seabirds at risk around offshore oil platforms in the north-west Atlantic. Marine Pollution Bulletin 42:1285-1290. https://doi.org/10.1016/S0025-326X(01) 00096-0

Wiese, F. K., and G. J. Robertson. 2004. Assessing seabird mortality from chronic oil discharges at sea. Journal of Wildlife
Management 68:627-638. https://doi.org/10.2193/0022-541X (2004)068[0627:ASMFCO]2.0.CO;2

Wilbur, H. M. 1969. The breeding biology of Leach's Petrel Oceanodroma leucorhoa. Auk 86:433-442. https://doi.org/10.2307/4083406

Wilcox, C., E. V. Sebille, and B. D. Hardesty. 2015. Threat of plastic pollution to seabirds is global, pervasive, and increasing. Proceedings of the National Academy of Sciences of the United States of America 112(38):11899-11904. https://doi.org/10.1073/ pnas. 1502108112

Wilhelm, S. I., A. Hedd, G. J. Robertson, J. Mailhiot, P. M. Regular, P. C. Ryan, and R. D. Elliot. 2019. The world's largest breeding colony of Leach's Storm-Petrel Hydrobates leucorhous has declined. Bird Conservation International https://doi. org/10.1017/S0959270919000248

Wilhelm, S. I., J. Mailhiot, J. Arany, J. W. Chardine, G. J. Robertson, and P. C. Ryan. 2015. Update and trends of three important seabird populations in the western North Atlantic using a geographic information system approach. Marine Ornithology 43:211-222. [online] URL: http://www.marineornithology. $\mathrm{org} /$ content/get.cgi?rn=1133

Zabala, J., I. Zuberogoitia, J. A. Martínez-Climent, and J. Etxezarreta. 2011. Do long lived seabirds reduce the negative effects of acute pollution on adult survival by skipping breeding? A study with European Storm-Petrels (Hydrobates pelagicus) during the "Prestige" oil-spill. Marine Pollution Bulletin 62:109-115. https://doi.org/10.1016/j.marpolbul.2010.09.004
Editor-in-Chief: Keith A.Hobson Subject Editor: Alexander L.Bond
Sponsored by the Society of Canadian Ornithologists and Birds Canada

Parrainée par la Société des ornithologistes du Canada et Oiseaux Canada

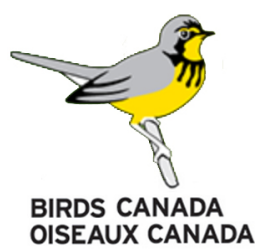

